\title{
Triumph and Tragedy Associated with Aboriginal Self Governments in Canada: the Cases of the James Bay, Nisga'a, Nunavut and Tsilhqot'in People(s)
}

\author{
Erin McEntee - Dalhousie University
}

\section{Introduction}

Canada's current population presents a complex mosaic of citizens each belonging to rich and unique cultural, religious, social, and ethnic groups. Urban centres like Toronto, Montreal, and Vancouver are activity-rich hubs of people from a variety of different backgrounds. While the concept of Canada as being a cultural assortment is relatively modern, there are faces in the national crowd that belong to a long-standing group of marginalized peoples - Canada's aboriginal population. The Aboriginal people of Canada have resided in the nation's regions long before the official creation of the country itself. Moreover, they have been operating within established, organized societies and communities well before the assertion and acquisition of sovereignty by the Crown as well as prior to the establishment of settler societies and governments (Luk). As such, the Aboriginal people of Canada have been part of a long and gruelling process to attain varying levels of self-government in the fight to gain back their rights as individuals and as a distinct Aboriginal nation.

In Canada, there are currently 22 self-government agreements for Aboriginal people in 36 different communities across its vast geographical stretch (Government of Canada). These self-government agreements, signed between the federal government of Canada and a variety of different Métis, First Nations, and Inuit communities in Canada, allocate varying degrees of powers to communities as defined by modern treaties, as well as various agreements that have been established in the past. While some powers associated with self-government agreements in Aboriginal communities are comparable to those of Canadian Municipalities, such as the Inuit of Nunavik in Northern Quebec (Papillon, The Rise (and Fall?) Of Aboriginal SelfGovernment), others constitute a far greater range of power, as can observed in the creation of Inuit-dominated government in Nunavut (Wherrett).

This essay will explore how the term "self-government" manifests itself within the context of the Canadian federation by evaluating some key self-government agreements in Canadian history, beginning with an overall consideration of self government and what it entitles in Canada. It will examine the James Bay and Northern Quebec Agreement (JBNQA) as well as elaborate upon its relative successes and faults. Following the evaluation of the JBNQA 
and its style of governance, this essay will go on to reflect upon public governance and selfgovernment in the Nisga'a, Yukon, and Nunavut regions. After examining the many folds and creases associated with the elaborate fabric of self-government in Canada, it may be concluded that while Aboriginal self-government has been implemented in a number of ways in attempt to meet the needs of Aboriginal peoples, the end results have been less than satisfying for the aboriginal people of Canada.

\section{Aboriginal-Canadian Self Government: An Overview}

Before examining the specific employments of aboriginal self-government currently operating in Canada, it is important to first examine what the term self-government constitutes. In the Canadian context, the term is far too complex to evaluate in one simple definition. Aboriginal self-government in Canada exists in a multifaceted variety of forms, so as to cater to the varying needs of different communities, such as territorial rights, trapping, hunting, and fishing rights, or administrative rights (Rynard, Welcome In, But Check Your Rights at the Door" : The James Bay and Nisga'a Agreements in Canada).

Aboriginal self-government is a highly important annexation within Canadian federal context. It operates alongside the federation's sphere of multi-level governance, so as to grant a degree of jurisdictional power to a distinct body, or peoples, residing within Canada. It serves to legislate delegated autonomy to said people, so as to serve their distinctive, individual aboriginal needs.

Autonomy, in some instances of self-government, may be attained through the delegation of authority from state level to a local level - similar to municipal power. Alternatively, some aboriginal individuals may view self-governmental power as their inherent right, as ingrained in section 35(1) of the Canadian constitution. Lastly, some scholars, aboriginal and non aboriginal alike, have argued for powers constituting coexistent sovereignty wherein aboriginal powers would be acknowledged outside the binds of the Canadian constitution (Papillon, The Rise (and Fall?) Of Aboriginal Self-Government).

Regardless of the type of self-government that is attained, it all must first be brought about by means of negotiation between a combination of federal, provincial, local, and aboriginal governments (Rynard, Welcome In, But Check Your Rights at the Door" : The James Bay and Nisga'a Agreements in Canada). Negotiation of self-government is often a tedious, lengthy process. From the development of framework principles to the actual ratification and implementation of an agreement, the entirety of the process can take anywhere from a year to a decade (Russell). The majority of these self-government negotiations arise out of issues between aboriginal community and federal or provincial governments, pertaining to larger land claim settlements. Especially in recent years, as the 
resource extraction economy in Canada has expanded exponentially, and the federal and provincial governments have begun to engage more frequently in negotiations over aboriginal rights and titles (Papillon, The Rise (and Fall?) Of Aboriginal Self-Government). As a result, aboriginal communities across Canada have been driven to voice their concerns for their lands, their rights, and their sovereignty.

\section{The Beginning of Canadian Aboriginal Self Government: 1975 James Bay and Northern Quebec Agreement (JBNQA)}

Self-governance first came into prominence in Canada with the JBNQA; this involved an agreement with the James Bay Cree's and the Inuit of Nunavik in Northern Quebec. Spurred by the development of a hydroelectric plant on aboriginal lands, this development prompted the Cree and Inuit people of the regions to enter into negotiations with the federal governments (Papillon, The Rise (and Fall?) Of Aboriginal Self-Government). Such negotiations were brought into the federal limelight after the then premier of Quebec, Henry Bourassa, autonomously decided to construct a power plant serving the Quebec-owned utility, Hydro-Québec, on aboriginal lands in 1971. Prior to the affirmation of such decisions made by Bourassa, the Quebec government, in regards to personnel and institutional presence, had previously had very limited presence in the Cree communities in Northern Quebec. While the federal and provincial governments largely governed the communities' rights, such a fact was not so apparent in the aboriginal communities' day-to-day activities (Rynard, Ally or Colonizer?: the Federal State, the Cree Nation and the James Bay Agreement.)_Negotiations concerned the redistribution of aboriginal territorial rights to the federal government in exchange for monetary compensation, specific hunting, trapping, and fishing rights as well as a series of new administrative arrangements allowing for management of governmental programs in native communities (Coates). In some ways, the JBNQA was ground breaking in that it was the first ever self-government deal created in Canada. While the delegated autonomy was not much, it was a start. _Firstly, it allocated jurisdictional powers to the Cree, and later the Naskapi in 1978, that limited the federal government's ability to regulate day-to-day administrative action within the communities, essentially allowing the Cree people to create by-laws that were not subject the ministerial veto. Secondly, it allowed the Nunavik Inuit a degree of autonomy comparable to that of a local government. They currently possess regional powers over their whole northern constituency, including the municipalities (Rynard, Welcome In, But Check Your Rights at the Door" : The James Bay and Nisga'a Agreements in Canada). While the first attainment of a binding form of self-government was a significant feat for Aboriginal people all across Canada, the JBNQA faltered in many aspects. Although the Cree, Inuit, and Naskapi people may have seen some slight improvements in socio-economic terms, their quality of life following the enactment of the agreement and the original aims of the agreement's 
aboriginal signatories were not met (Rynard, Welcome In, But Check Your Rights at the Door" : The James Bay and Nisga'a Agreements in Canada).

At the birth of the JBNQA, the primary goal of the aboriginal parties was to obtain a greater level of control over their quickly evolving social and economic environment. When cast in this hopeful light, the agreement was a severe disappointment, as it followed the same, long-standing models of state-led and state-regulated development, as seen in aboriginal communities for years prior to the agreement (Papillon, The Rise (and Fall?) of Aboriginal Self-Government). Moreover, in some circumstances, the agreement actually further damaged sociological aspects of certain aboriginal communities. For example a Cree community under the agreement, the Chisasibi, were forced to relocate away from the community's neighbouring La Grand River due to altered. This relocation instilled a certain sense of sociological damage in the community; fish is a staple in traditional Cree diets. As an aside, the hydroelectric plant that actually was implemented (though not to the originally intended extent) caused fish to contain higher levels of mercury, thereby poisoning several members of the Chisasibi community (Rynard, Ally or Colonizer?: the Federal State, the Cree Nation and the James Bay Agreement.).

In addition to a lack of recognition of the sociological affects that were brought on by the agreement, a lack of intergovernmental coordination mechanisms and formal dispute resolutions made for highly strained governmental relationships (Russell). Furthermore, prior to the agreement, a common conception among political elites was that aboriginal rights simply entailed vague and out-dated hunting and fishing rights, which could be said to have translated into the actual negotiations (Rynard, Ally or Colonizer?: the Federal State, the Cree Nation and the James Bay Agreement.). Finally, upon regarding the means by which powers in the JBNQA were established, it is appropriate to claim that they did not suffice to the extent that the aboriginal people in the JBNQA communities would have hoped (Russell). Abel and Prince (2009 p573) state, "We have encountered no Aboriginal nations, no matter how small, that have identified the mini-municipality model as their ultimate goal."

It may be surmised that while the creation of aboriginal self-government, in the case of the JBNQA and the Cree, Inuit, and Naskapi people, was significant in it's sheer conception, the actual content and framework of the agreement was lacking and in some cases even detrimental, considering the extent to which it catered to the aboriginal people's wishes and needs. 


\section{The Second Wave of Self-Government Agreements in Canada; Considering the Nisga'a and Nunavut Self-Government Agreements}

Following the trials of self-government that played out with the JBNQA, other Aboriginal people across Canada were watching from the sidelines and envisioning their own ideas and revisions of how they believed self-government could be run more effectively. Like with the JBNQA, land claim agreements spurred the development of self-government in the case of the Nisga'a Final Agreement in 1998, as well as through the creation of Nunavut in 2000 (McNeil). The aboriginal signatories involved with these agreements noted that the JBNQA was greatly ignorant of the recognitions concerning the idea of self-government based on pre-existing aboriginal sovereignty. This is to say that following the JBNQA, what were prior to the agreement, considered to be Aboriginal rights then became treaty rights; section 2.1 of the JBNQA was thereafter known as the infamous extinguishment clause, as it essentially replaced pre-existing, sovereign aboriginal rights with those as acknowledged in the treaty (Rynard, Ally or Colonizer?: the Federal State, the Cree Nation and the James Bay Agreement.). Therefore, the Nisga'a people adopted slightly different models to try and achieve their aims (Papillon, 2014).

Up until 1990, the British Colombian government was largely impartial and ignorant of the Nisga'a people's political pleas and protests for increased territorial rights. In fact, Nisga'a chiefs have been struggling for greater land rights in the political arena since the 1880's (Rynard, Welcome In, But Check Your Rights at the Door" : The James Bay and Nisga'a Agreements in Canada). While the Nisga'a people had a significantly small portion of allocated reserve to begin with, predominantly white societies continued to expand their developments onto Nisga'a land, eating away at aboriginal territory year after year. This long-existing clash for increased sovereignty and political rights coupled with resistance from the British Colombian government cultivated a very harsh political environment, and thereby branded the eventual creation of the Nisga'a Final Agreement a significant achievement (Rynard, Welcome In, But Check Your Rights at the Door" : The James Bay and Nisga'a Agreements in Canada).

The Nisga'a Final Agreement serves as a particularly unique form of self-government in Canada as it allows the Nisga'a people to hold distinct legislative power within a province (Papillon, 2014). The agreement covers 1,992km on both sides of British Colombia's Nass River, and the communities hold ownership to mineral, oil, gas, and forests within the territory (Papillon, 2014). Compared to the James Bay Agreement, which allocated a mere $5600 \mathrm{~km}$ of land to be shared amongst nine different Aboriginal communities, this is a great improvement in terms of aboriginal self-government land claims in Canada (Papillon, Aboriginal Quality of Life Under Modern Treaty). The governmental structure associated with the Nisga'a Final Agreement establishes the Nisga'a Lisims Government and four Village 
Governments. Their law making authority allows for the evaluation of matters such as culture, language, public works, traffic regulation, solemnization of marriages, and land use within the Nisga'a territory (Wherrett).

Nisga'a Final Agreement flourishes compared to that of James Bay and Northern Quebec. But standing alone, it still does not match the ultimate expectations of the aboriginal people. The agreement presents a lack of authority in respect to the Nisga'a concerning wildlife, fisheries, and environmental protection, ultimately demonstrating the lack of cooperative management between Nisga'a self-government and the federal and provincial government that is claimed (Russell). Moreover, the territorial expanse of Nisga'a land is not great enough for them to sustain completely off of their own land-based revenue, meaning they must rely on the federal, provincial, and territorial governments for support (Russell). Finally, on a broader note, Rynard (2000) claims that given the extensive, gruelling history of repression faced by the Nisga'a community, the generalized meaning of equality does not suffice, and the final agreement does not sufficiently illustrate any special consideration of obligations of the federal government on behalf of a shared and tumulus colonial past. Thus, it may be concluded that while the Nisga'a Final Agreement fulfills the needs of the aboriginal community to an extent, its granted level of autonomy and jurisdiction is not fully satisfactory.

Following the initiation of the Nisga'a Final Agreement in 1995 came the Tapirisat Inuit's proposal to the federal government for the creation of a new territory in 1976. Twenty-three years later, in April of 1999, Canada's great northern territory, Nunavut was officially born (Nunavut Tunngavik Inc.). Aboriginal self-government in Nunavut is considerably different from self-government found in other regions across Canada. The Nunavut government is delegated, by the federal government, a bundle of powers that are almost analogous to those of the provinces with the exception of some natural resources (Papillon, The Rise (and Fall?) Of Aboriginal Self-Government). The Inuit majority residing in the territory controls the Nunavut government, but permits non-aboriginal persons to vote and have their fair say on governmental matters. As the Nunavut governmental system largely promotes the Inuit values, culture, interests, and languages as a theme in public policy, it may be regarded as a form of aboriginal self-government within Canada (Nunavut Tunngavik Inc.).

Nunavut self-government does relatively well in meeting the needs of Canada's northern aboriginal people; it provides them with a large degree of jurisdiction and control over their land, guaranteeing them a certain level of equality to the provinces in Canada. But, as with almost all other aboriginal self-government agreements in Canada, it is coupled with its own respective set of issues. Firstly, while the aboriginal funding structure of the Nunavut government is considerably better compared to those of other aboriginal self- 
government agreements in Canada, the territory still struggles with limited budgets and serious socio-economic challenges. Currently, the territory relies on the federal government for $90 \%$ of its revenues, and its federal transfers over the next 10 years will amount to approximately 1.1 billion CAD. While such funding is necessary for the creation of new territorial governance structures, true self-governmental autonomy would require a stable source of revenue for Nunavut - revenue that would liberate the territory of its federal dependence (Elder). In addition to this, Nunavut's 25 communities are scattered all over a large expanse of Canada's north and are largely independent of each other, as well as southern Canada. Therefore, oftentimes they are each required to spend a significant amount of funding on essential infrastructure, such as airstrips, health centers, and power plants despite the small populations residing in these areas (Nunavut Tunngavik Inc.). All of this considered, a significant toll is taken on the programs and services that the Nunavut government is able to provide to its people, and signals a drastic need for an improved economic development plan in the territory (Nunavut Tunngavik Inc.). Such needs will perhaps call for a greater devolution of responsibility in the future from the federal government to the territorial government in Nunavut, so as to allow the Nunavut government to reach greater autonomy; however it should be noted that the territory is not yet ready to attain such goals (Elder).

Overall, it may be said that the model of aboriginal self-government that is currently enacted in Canada's northern territory of Nunavut is relatively sufficient when in contrast with other forms of self-government in Canada, however it's form of self-government still carries its own set of difficulties and needs for greater improvement.

\section{Canadian Aboriginal Self Government in the 21 st Century: Tsilhqot'in Nation v. British Columbia and Taiaiake Alfred's Dissent}

A modern example of current aboriginal self-government in Canada is the Tsilhqot'in people and their declaration of official Aboriginal title in 2014, as awarded by the Supreme Court of Canada. Such a notion refers to the inherent right that aboriginal people hold concerning their lands and territories. This served as the first time that Canada has ever awarded Aboriginal title to aboriginal people for lands off of a reserve, and thereby shall serve as a marked historical advancement for Aboriginal self-government in the nation. In this case, the Tsilhqot'in people were given approximately $1900 \mathrm{~km}^{2}$ of the claim area, thereby indicating that this declaration of Aboriginal Title is not restricted to a small, intensively used area, as is often the case, but rather extends to all of the territory that is, and has been, exclusively and intensively used by the Tsilhqot'in people prior to the Crown's acquisition of sovereignty (Tsilhqot'in National Government). Moreover, such an attainment of Aboriginal title allows for the Tsilhqot'in people to control the land in whichever manner they please. Overall, this form of allotted self-government to aboriginal people marks a 
significant development and acknowledgement of Aboriginal needs in terms of governance on behalf of the federal government - however, this is only to an extent. While scholars, aboriginal and non-aboriginal alike, acknowledge the fact that the Supreme Court's declaration of Aboriginal title in the case of the Tsilhqot'in nation was a great success for Aboriginal self-government in Canada, one aboriginal scholar claims that such is still very lacking in terms of meeting modern Aboriginal needs. Aboriginal scholar and rights activist Taiaiake Alfred provides a substantial degree of criticism circling the declaration; in fact, he claims that it was hardly a triumph at all. He bases this judgement off of the notion that historically, the recognition of Aboriginal people's rights as a sovereign notion existed thereby indicating that the seemingly never ending struggle for increased rights and increased autonomy on behalf of Aboriginal people is not a new or fresh concept; rather, it's a demand for the state to return to what it originally indicated when the Crown attained sovereignty of the lands (Alfred, Cultural Strength: restoring the place of indigenous knowledge in practice and policy). Alfred also refers to his own Mohawk ancestor's notion of Guswhenta, meaning two-row-wampum in English. This belief entails the illusion of interdependence, partnership, and a sharing of the lands on the basis of mutual agreement, as was pioneered on behalf of the early Canadian governments and Aboriginal peoples (Alfred, Pathways to an ethic of struggle). Alfred looks to the Tsilhqot'in agreement and notes its final paragraph; a paragraph that acknowledges that the terms of the agreement shall stand only if they do not contradict national interest. This is to say that technically, it is within the jurisdictional abilities of the Canadian government to undermine Aboriginal authority should national interests (e.g. national resources) prevail (Alfred, Cultural Strength: restoring the place of indigenous knowledge in practice and policy). While in making the ruling, the Court did acknowledge that infringements to the Aboriginal title on behalf of the government would not be taken lightly (Tsilhqot'in National Government), it could be said that in accordance with historical notions of Gushwenta, such an agreement still does not meet the expectations and desires of Canada's Aboriginal people.

\section{Cogitating Failed Self Government Agreements in Canada: A lack of} Cultural Revitalization

Upon reviewing the various different cases of Aboriginal self-government agreements in Canada, it maybe be surmised that each case presents a disconnect between the central government and Aboriginal people, and each agreement ultimately portrays a lack of understanding of Aboriginal needs. While each agreement presents an array of problems and externalities that warrant extensive reviews in themselves, a common theme associated with many self-government agreements in Canada is a lack of cultural revitalization (Alfred, Cultural Strength: restoring the place of indigenous knowledge in practice and policy). That is to say that the agreements do not account of the imposition of colonial values into aboriginal culture, as well as in many cases an erasure of culture for 
Aboriginal youth. While many Aboriginal self-government agreements in Canada acknowledge jurisdictional responsibilities associated with governance and land claims, little to none acknowledge the historical obligations of the federal government to facilitate programs in Aboriginal communities to allow youth to learn and relearn their traditional cultural practices. Such programs could involve the maintenance of language fluency or the teachings of traditional practices (Burack). In Northern Quebec, a similar program was implemented within a Cree community; the results were successful. Cree youth who partook in this program showed an enhanced ability to integrate into both Canadian, and Cree communities - both on the reserve and in the city - and thereby were able to surpass many of the socio-economic problems that frequently encounter Canada's aboriginal people (Alfred, Cultural Strength: restoring the place of indigenous knowledge in practice and policy).

Should future self-government agreements in Canada take into account notions of cultural revitalization, coupled with Aboriginal needs for increased jurisdictional powers separate to those of the Canadian government, Canada's Aboriginal population may be able to begin to reach a fair and equal stakeholder status throughout the nation's vast territory.

\section{Conclusion:}

Based on the current models of self-government in Canada, the Aboriginal people have gained only a small slice of autonomous powers that, while complying with some of their basic sovereignty needs, do not encompass many fundamental legislative requirements for which Canada's aboriginal communities strive. This point can be understood through examining four main crucial case studies concerning aboriginal selfgovernment in Canada. The first case study, the JBNQA, played a significant role as it was Canada's first ever self-government agreement. The qualms of the JBNQA though were that it did not notably defer from previous models of state led governance and thereby did not fully satisfy the aims of the aboriginal people involved. Secondly, the Nisga'a final agreement succeeded in establishing a greater degree of long sought-out rights pertaining to land claims and a well developed governmental structure for the Nisga'a communities. However, given the Agreement's lack of resource co-management, their dependence on fiscal aid from the federal government, as well as its lack of acknowledgement of past repressions faced by the Nisga'a people, it too fails to meet the ultimate goals striven for by the aboriginal people. In looking to the creation of Canada's territory Nunavut, it may be surmised that public government model that ultimately represents aboriginal self-government in the region shines compared to other self government agreements found across Canada. The autonomy given to the Inuit people in Nunavut is comparable to that which is given to the provinces, thereby declaring the development of Nunavut's public government a great achievement for the aboriginal community in Canada. That being said, the territory still struggles with financial management, and various socio-economic challenges that have resulted largely as 
a part of the terms on which its government is negotiation. Finally, in considering the most recent and thereby significant of the Aboriginal self-government agreements in Canada, the Tsilhqot'in's attainment of the first ever awarded Aboriginal title, it may be surmised that self-government agreements in Canada are making substantial advancements. Comparatively, such an agreement flourishes in terms of acknowledging pre-existing Aboriginal entitlements, however it could be said that it still is lacking in the sense that the Canadian government continues to hold centralized power over the jurisdictional abilities as they are delegated to the Tsilhqot'in people.

As it has been demonstrated that self-government agreement's in Canada very rarely meet the expectations of Aboriginal People, a suggestion for future agreements might entail elements of cultural revitalization programming. Should the Canadian government wish to further develop and improve upon the negotiation and establishment of self-government agreements with the Aboriginal population, it may consider including or facilitating the implementation of educational, cultural programs relating to Aboriginal tradition and history. To implement such programs alongside self-government agreements could potentially expedite the success said agreements in the future.

Clearly, while the development of self-government in Canada has evolved considerably, it still warrants a substantial level of development and improvement on a variety of fronts. After reflecting upon the experiences that Canada's aboriginal peoples have undergone concerning self-government agreements, it may be surmised that said agreements do not assure the social and economic well being of aboriginal communities, nor do they, necessarily, drastically alter the relationship between aboriginal communities and the state. Ultimately, it may be speculated that the current lack of fulfillment of aboriginal needs as demonstrated through various self-government agreements across Canada is troubling, and certainly highlights the subjectivity of aboriginal self-government to the Canadian government's greater political agendas. While past agreements may not have been absolutely sufficient, the progress as demonstrated with each successive agreement indicates that possibility for improvement of future Aboriginal self-government agreements in Canada is very conceivable and will entertain very promising outcome. 


\section{Bibliography}

Abele, Frances, and Michael J Prince. "Four Pathways to Aboriginal Self-Government in Canada." American Review of Canadian Studies (Tandfonline) 36, no. 4 (November 2009): 568-595.

Alfred, Taiaiake. "Cultural Strength: restoring the place of indigenous knowledge in practice and policy." Australian Aboriginal Studies (Academic Search Premier), no. 1 (2015): 3-11.

Alfred, Taiaiake. "Pathways to an ethic of struggle." Canadian Dimension (Alternative Press Index) 41, no. 1 (January): 35-39.

Burack, Jacob A. "Developmental perpectives on the role of cultural identity in well-being: Evidence from abiriginal communities in Canada." Cultural and contextual perspective on developmental risk and well-being (Cambridge University Press), 2014: 81-103.

Coates, Ken. "The Indian Act and the Future of Aboriginal Governance in Canada." Research Paper, National Centre for First Nations Governance, 2008.

Elder, Beth. "Aboriginal Self-Government in Nunavut." Sovereignty and Intervention, 2012: 21-33.

Government of Canada. "Fact Sheet: Aboriginal Self-Government." Indigenous and Northern Affairs Canada. April 2015. http://www.aadncaandc.gc.ca/eng/1100100016293/1100100016294 (accessed Novemeber 15, 2015).

Luk, Senwung. "Confounding Concepts: The Judicial Definition of the Constitutional Protection of the Aboriginal Right to Self-Government in Canada." Ottawa Law Review (University of Ottawa) 41, no. 1 (2009).

McNeil, Kent. "A Brief History of our Right to Self-Governance, Pre-Contact to Present." National Centre for First Nations Governance (First Nations Governance), March 2007: 16-20.

Nunavut Tunngavik Inc. Nunavut's Economic Challenges . Brief, Tunngavik, 2006.

Papillon, Martin. "Aboriginal Quality of Life Under Modern Treaty." Instiitute for Reaserch on Public Policy. August 26, 2008. http://irpp.org/research-studies/choices-vol14no9/ (accessed November 17, 2015).

Papillon, Martin. "The Rise (and Fall?) Of Aboriginal Self-Government." Canadian Politics (University of Toronto Press), 2014: 117-123.

Russell, Dan. A People's Dream: Aboriginal Self-Government in Canada. Vancouver, B.C.: UBS Press, 2000.

Rynard, Paul. "Ally or Colonizer?: the Federal State, the Cree Nation and the James Bay Agreement." Journal of Canadian Studies 36, no. 2 (2001): 8-41.

Rynard, Paul. "Welcome In, But Check Your Rights at the Door" : The James Bay and Nisga'a Agreements in Canada." Canadian Journal of Political Science (York University) 33, no. 02 (June 2000): pp 211-243.

Tsilhqot'in National Government. "Tsilhqot'in National Government." tsilhqotin. 2014. http://www.tsilhqotin.ca/PDFs/2014_07_03_Summary_SCC_Decision.pdf (accessed March 31, 2016). 
Wherrett, Jill. Aboriginal Self-Government . Governmental , Political and Social Affairs, Parliamentary Research Branch, Library of Parliament, 1999. 